\title{
Development Stage of Tourism Objects in Malang Regency, East Java
}

\author{
Khansa Cintya Pradipta Hapsari, M. H. Dewi Susilowati*, and Ratri Candra Restuti \\ Department of Geography, Universitas Indonesia, Jalan Margonda Raya, Pondok Cina, Beji, Kota \\ Depok - Indonesia
}

\begin{abstract}
Malang Regency has many tourism potentials such as natural attraction and cultural attraction. Tourism potentials need to be supported by facilities and infrastructure that are optimal for the development so that they can attract tourists. Some tourism objects in Malang Regency does not have complete facilities to support tourist. This study aims to determine the development stage of tourism objects and analyze the correlation between development stage of tourism objects with tourism organizer. Variables used in this research are the development stage of tourism objects and tourism organizer. The methods used are spatial descriptive analysis and chi-square statistical analysis. The results showed that the stage development of tourism objects in Malang Regency are dominated by the second stage of development (involvement) with natural attraction that tend to have a higher development stage than cultural attraction. Chi-square statistical test result showed that there is a significant correlation between development stage of tourism in Malang Regency with tourism organizer.*
\end{abstract}

Keywords: Tourism objects, development stage, tourism organizer

\section{Introduction}

In 2018, tourism sector became one of the leading sectors contributing to Indonesia's secondlargest foreign exhange after palm oil [1]. Therefore, tourism has become an economic sector used by many countries, including Indonesia to support economic development [7]. The development of tourism is strongly influenced by the number of tourism objects and the development of themself [8]. In order to develop, tourism object has certain conditions, which must have a variety of attractions, provide tourist facilities, easy accessibility and amenities to support the tourist activities when visiting the tourism object [6].

The conceptual framework of the Tourism Area Life Cycle (TALC) consists of six-stage of tourism development with each characteristics : Exploration (attraction still natural, difficult to access, limited primary facility, no secondary and conditional facilities), Involvement (facilities provided by local people, number of tourists increased slightly, no commercialization), Development (facilities begin to increase, easy access, significant increase number of tourists, tourism promotion, commercialization), Consolidation (number

\footnotetext{
* Corresponding author: mhdsusilowati@gmail.com
} 
of tourists increased but growth began to decline, tourist facilities need to be improved), stagnation (peak tourist numbers reached, tourism no longer popular), and post-stagnation (ranging from rejuvenation to decline) $[3,4]$. Post stagnation results also depend on the ability of tourism objects to find new markets [3].

One of the main values of Tourism Area Life Cycle (TALC) is that it integrating tourism with economy. This theory analyzes the stages of tourism development from the increasing number of tourists and the infrastucture expansion as a result $[3,4]$. The main aspect of tourism is connection. People are connected to tourism object physically by means of transportation, and spiritually by their interaction with and experiences at the tourism object. Stage of tourism object is measured with five main components, namely number of tourist, attractions, shopping facilities, infrastructure, food and shelter [3].

Malang Regency is located at an altitude of 0-2000 meters above the sea level that makes Malang Regency has a various topography from the lowland to hilly. The topographies provide various kind of natural attractions, such as beaches, waterfalls and even mountains. Not only natural attractions, they also have cultural attractions like temples. Many tourism objects in Malang Regency does not have complete facilities to provide tourist. The number of facilities depend on the development that is done by the tourism organizer. For this reason, the purposes of this study are to determine the development stage of tourism object and analyze the correlation with tourism organizer.

\section{Methodology}

\subsection{Research Area}

Figure 1 shows the distribution of tourism objects in Malang Regency. This research observed 17 locations of tourism object in Malang Regency. The tourism object consist of natural and cultural attractions, such as Tamban Indah Beach, Sendang Biru Beach, Tiga Warna Beach, Teluk Asmara Beach, Goa Cina Beach, Watu Leter Beach, Ungapan Beach, Nganteb Beach, Balekambang Beach, Ngliyep Beach, Rondo Waterfall, Pelangi Waterfall, Bidadari Waterfall, Badut Temple, Jago Temple, Kidal Temple and Singosari Temple. 


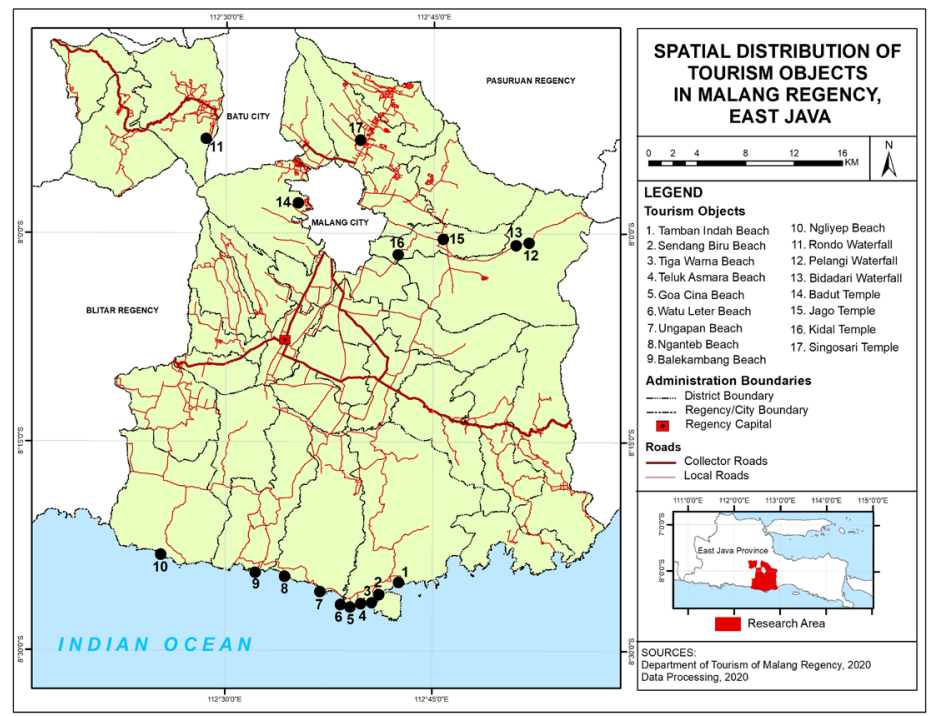

Fig. 1. Spatial Distribution of Tourism Objects in Malang Regency

\subsection{Data Collection}

The data needed for this research are the number of tourists, primary facilities (site attraction and event attraction), secondary facilities (the number of restaurants, hotels and souvenir shop), conditional facilities (the number of public toilet, place of worship and availability of parking lot), accessibility (road function and public transportation), promotion, commercialization and tourism organizer. Data on the number of tourists used is the growth of tourists in the last 5 years (2015-2019). Whereas the newly opened tourism objects in the last 5 years, will be seen based on the initial year the tourism object is opened.

Data of the number of tourists at each tourism objects and promotional activities are obtained from the tourism organizer. To collect the number and type of tourism facilities will be carried out by direct observation and to determine the absolute location of facilities by using Avenza Maps. The availability of public transportation and types of road classes were obtained from Malang District Transportation Office. Data of commercialization is obtained by direct observation of the cost or entrance ticket to enter each tourism objects.

\subsection{Data Processing}

There are several steps in data processing: 1) Adding the existing facilities on each tourism objects, then multiplying the number of facilities by the weighting values listed in table 1 [6]. If a tourism objects does not have facility, then will be filled with a value of 0 . The weight value of each tourism objects is added to determine the development stage of the tourism objects; 2) Classifying tourist growth within a certain time period, classifying facilities (primary, secondary and conditional facilities); 3) Data will be processed spatially with GIS (Geographic Information System) and maps as the output; 4) Analyzing the relationship between the development stage of tourism objects in Malang Regency and tourism organizer using SPSS software. 
Table 1. Variable Weight Determination of Tourism Object Development Stage

\begin{tabular}{|c|c|c|}
\hline Variable Type & Variable Name & $\begin{array}{c}\text { Weight } \\
\text { Value }\end{array}$ \\
\hline \multirow{2}{*}{ Primary Facilities } & Site attraction & 0.375 \\
\cline { 2 - 3 } & Event attraction & 0.07 \\
\hline \multirow{2}{*}{$\begin{array}{c}\text { Secondary } \\
\text { Facilities }\end{array}$} & Hotel & 0.11 \\
\cline { 2 - 3 } & Restaurant & 0.106 \\
\hline \multirow{2}{*}{$\begin{array}{c}\text { Conditional } \\
\text { Facilities }\end{array}$} & Gift shop & 0.083 \\
\cline { 2 - 3 } & Place of Worship & 0.023 \\
\cline { 2 - 3 } Accessibility & Public toilet & 0.021 \\
\hline \multirow{2}{*}{$\begin{array}{c}\text { Parking lot } \\
\text { Promotion }\end{array}$} & transportation & 0.019 \\
\cline { 2 - 3 } & Road Function & 0.072 \\
\hline Promotion media & 0.076 \\
\hline
\end{tabular}

\subsection{Data Analysis}

This research used spatial descriptive analysis and quantitative analysis with chi-square. Spatial descriptive analysis was used to explain the characteristics of each tourism objects and to tell the similarity and differences between each development stage. Chi-square analysis was used to determine the correlation between development stage of tourism objects with tourism organizer. If the result of chi-square test shows the probability value is greater than 0.05 meaning that there is significant correlation between development stage and tourism organizer $[9,10]$. After obtaining the chi-square value, then examine the strength of the correlation. The value of contingency nominal showed in symmetric measures table explain the strength of the correlation. The closer value to 1 meaning that the correlation between the two variables is getting stronger $[9,10]$

\section{Result and Discussion}

\subsection{The Development Stage of Tourism Objects}

The development stage of tourism objects in Malang Regency is obtained based on the analysis of the number of tourists, facilities, accessibility, commercialization and promotion. Tourism objects in Malang Regency are included in the four stages of tourism object development, namely first stage (exploration), second stage (involvement), third stage (development) and fifth stage (stagnation). Natural attractions in Malang Regency tend to have a higher development stage than cultural attraction. Figure 2 shows a chart between the number of tourists in a period of time and the stage development of tourism objects. The higher the stage of development, the increasing number of tourists except at the stage of decline which has decreased tourists. 


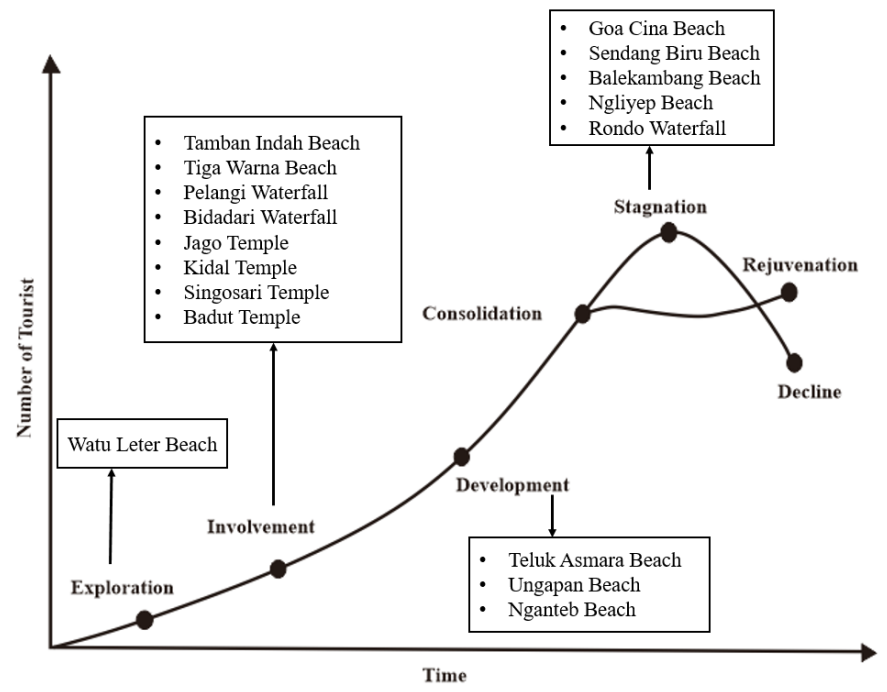

Figure 2. Chart of Stage Development of Tourism Objects in Malang Regency

Tourism object in Malang Regency that included in exploration stage is Watu Leter Beach. At the exploration stage, the number of tourists increased slightly and there were no secondary and conditional facilities. The primary facilities in exploration stage are only 3 attractions. Exploration stage also have characteristics which tourism objects do not have promotion and commercialization.

The second stage of tourism objects development included Tamban Indah Beach, Tiga Warna Beach, Pelangi Waterfall, Bidadari Waterfall, Jago Temple, Kidal Temple, Singosari Temple and Badut Temple. At the involvement stage, the primary facilities available for tourists are only 1 to 3 facilities. The availabilities of secondary and conditional facilities are also not diverse yet. The access to each tourism objects is easily accesible in the form of local roads. At this stage, there is no commercialization of tourism objects. The number of tourists at the involvement stage has increased although not too large, such as in the Pelangi Waterfall and Bidadari Waterfall. In other tourism objects, the number of tourists has increased but the growth of tourists has declined. This involvement stage is also marked by promotional activities on each tourism objects in the form of internet and banners.

The third stage development of tourism objects included Teluk Asmara Beach, Ungapan Beach and Nganteb Beach. The number of tourists in each of these tourism objects increased significantly. Primary facilities at the development stage have varied with numbers ranging from 4 to 8 . In addition, tourism objects at this stage have provided secondary and conditional facilities athough they are incomplete. Accessibility of each tourism object is very easily to access by means of public transportation. Promotion on each tourism objects has been done with the internet. The development stage also have an entrance ticket if the tourist want to visit.

The fifth stage development of tourism objects included Sendang Beach, Ngliyep Beach, Goa Cina Beach, Balekambang Beach and Rondo Waterfall. At the stagnation stage, the number of tourists increases but the growth of tourists begins to decline. All of the facilities at this stage are diverse and complete. The accessibility on each tourism object is very easy to access by the availability of public transportation. The tourism objects have been promoting tourism by using the internet. Tourists must pay for the entrance ticket if they want to visit the objects. Figure 3 shows map of stage development of tourism objects in Malang Regency. 


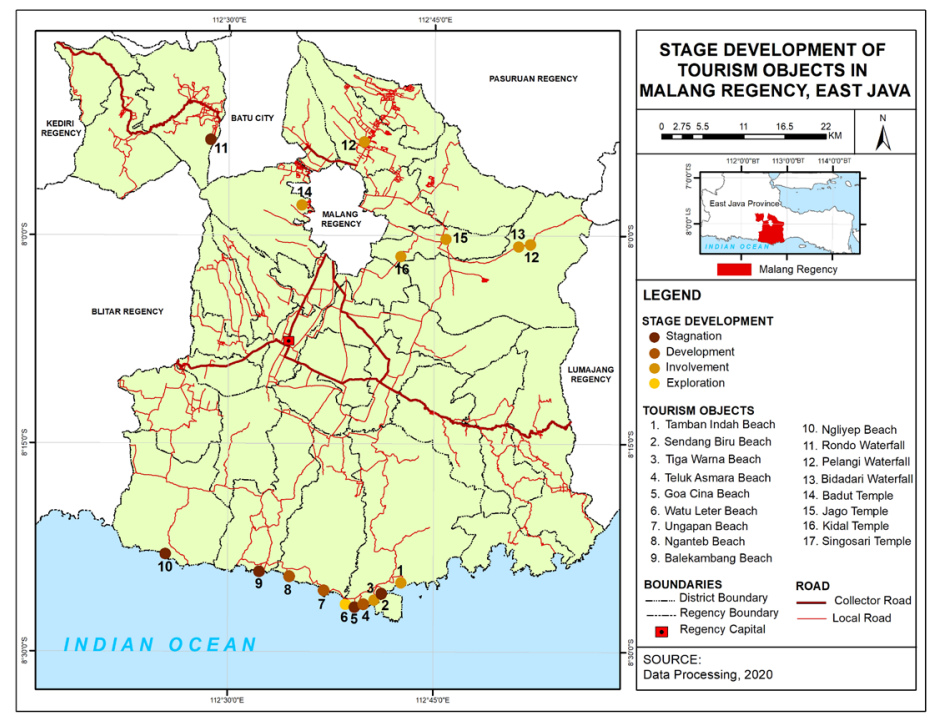

Fig. 3. Map of Development Stage of Tourism Objects in Malang Regency

Previous research on the development stage of tourism objects has been carried out in Bantul Regency [5]. The results of this study indicate that attractions in Bantul Regency are included in three stages of development, namely the involvement, development and consolidation stages. At the involvement stage there is an increase in the number of tourists although not large, secondary facilities available are only in the form of restaurants. At the development stage, the number of tourism objects in Bantul Regency is increasing. In contrast to tourism which is included in the development stage in Malang Regency has an increasing number of tourists but the growth of tourists is decreasing. At the stage of development of consolidation in Bantul Regency, the number of tourists visiting is still increasing. Whereas in Malang Regency, tourism objects included in the stagnation stage have an increasing number of tourists but their growth has begun to decline.

\subsection{The Correlation between The Development Stage of Tourism Objects with Tourism Organizer}

Attractions in Malang Regency are managed by the local communities, government and private sector. The development of tourism objects in Malang Regency based on the organizer are attached in Figure 3. The picture shows that the tourism objects in Malang Regency are mostly managed by the government. Attractions at the exploration stage are managed by the local community, attractions at the involvement stage are managed by the local community and government, attractions at the development stage are managed by the government and private sector, while attractions at the stagnation stage are managed by the government. 


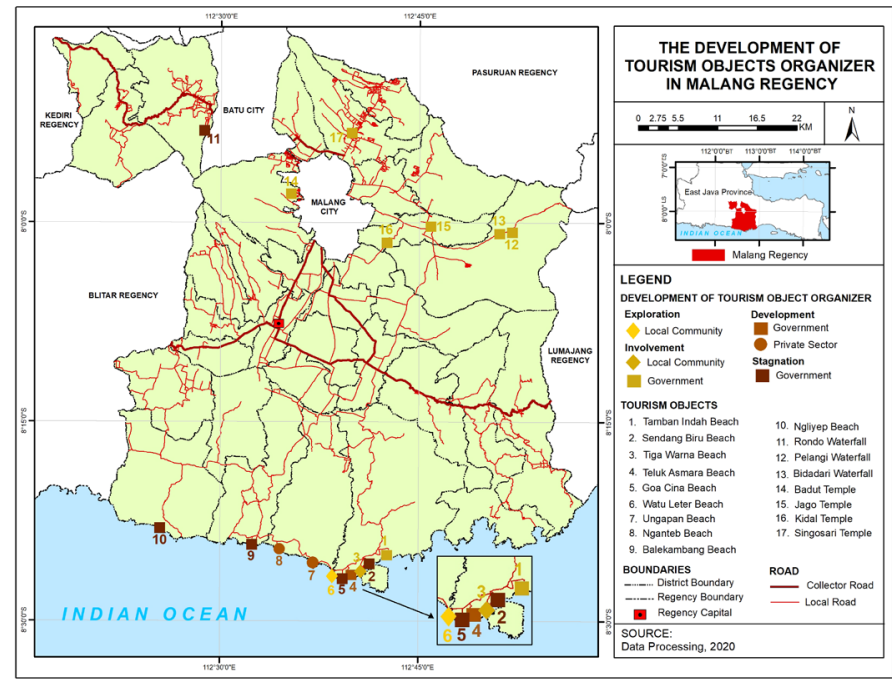

Fig. 4. Map of Development of Tourism Objects in Malang Regency Based on Tourism Object Organizer

Chi-Square statistical test results between the development stage of tourism objects in Malang Regency with the tourism organizer can be seen in table 2. The Chi-Square results show a probability value of 0.004 so that it can be concluded that there is a significant relationship between the development stage of tourism objects in Malang Regency with tourism organizer. The result of the contingency coefficient value is 0.725 , so both of them have a strong correlation. Based on crosstab, the exploration stage which is the first stage of the development of tourism object is managed by the local community, after being managed by the government and the private sector the tourist attraction stage increases to the next stage.

Table 2. Chi-Square Test Results between the Development Stage of Tourism Objects and the Tourism Organizer

\begin{tabular}{|ll|r|r|r|r|}
\hline \multirow{2}{*}{} & & \multicolumn{2}{|c|}{ Tourism Organizer } & \\
\cline { 3 - 6 } & $\begin{array}{c}\text { Local } \\
\text { Community }\end{array}$ & Government & Private Sector & \multirow{2}{*}{ Total } \\
\hline Stage Development of & Exploration & 1 & 0 & 0 & 1 \\
Tourism Objects & Involvement & 1 & 7 & 0 & 8 \\
& Development & 0 & 1 & 2 & 3 \\
& Stagnation & 0 & 5 & 0 & 5 \\
Total & 2 & 13 & 2 & 17 \\
\hline
\end{tabular}

Chi-Square Tests
\begin{tabular}{|l|r|r|r|}
\hline & \multicolumn{1}{|c|}{ Value } & df & $\begin{array}{c}\text { Asymptotic } \\
\text { Significance } \\
\text { (2-sided) }\end{array}$ \\
\hline Pearson Chi-Square & $18.880^{\mathrm{a}}$ & & 6 \\
Likelihood Ratio & 14.248 & & 6 \\
N of Valid Cases & 17 & & .004 \\
\hline
\end{tabular}

a. 11 cells $(91.7 \%)$ have expected count less than 5 . The minimum expected count is 12 .

\begin{tabular}{|c|c|c|}
\hline \multicolumn{3}{|l|}{ Symmetric Measures } \\
\hline & Value & $\begin{array}{l}\text { Approximate } \\
\text { Significance }\end{array}$ \\
\hline $\begin{array}{l}\text { Nominal by Nominal Contingency Coefficient } \\
N \text { of Valid Cases }\end{array}$ & $\begin{array}{r}.725 \\
17\end{array}$ & .004 \\
\hline
\end{tabular}




\section{Conclusions}

The stages of development of tourism objects in Malang Regency are included in four stages of development, namely the stages of exploration, involvement, development and stagnation. Tourism objects in Malang Regency are dominated by involvement stage with natural attractions that tend to have a higher development stage than cultural attractions. In tourism organizer, most of the attractions in Malang Regency are managed by the government. Based on the results of statistical tests, there is a significant relationship between the development stage of tourism objects in Malang Regency with tourism organizer. The exploration stage which is the first stage of the development of tourism object is managed by the local community, after being managed by the government and the private sector the tourist attraction stage increases to the next stage.

\section{References}

1. Badan Pusat Statistik, Jumlah Devisa Sektor Pariwisata, Jakarta: BPS (2018)

2. BPS Kabupaten Malang, Kabupaten Malang dalam Angka 2019, Malang: BPS (2020)

3. R. Burton, Travel Geography, London: Pitman Publishing (1995)

4. D. Bojanic, Tourist Area Life Cycle Stage and The Impact of A Crisis, ASEAN Journal on Hospitality and Tourism 4, 139-150 (2005).

5. A. S. Darajat, M. H. D. Susilowati, The Stage of Tourism Object Development in Bantul Regency Special Region of Yogyakarta, IOP Publishing 311, 1-5, (2019)

6. R. C. Mill, Tourism: The International Business edisi bahasa Indonesia, Jakarta: RajaGrafindo Persada, (2000)

7. K. W. Awang, W. M. Hassan, Zahari, Tourism Development: A Geographical Perspective, Asian Social Science 5, 67-76, (2009)

8. R. W. Butler, Alternative tourism: the thin edge of the wedge, Journal Tourism Alternatives: Potentials and Problems in The Development of Tourism, 302-321, (1992).

9. J. Sarwono, Metode Penelitian Kuantitatif dan Kualitatif, Yogyakarta: Graha Ilmu (2006)

10. D. Aidley, Introducing Quantitative Methods, United Kingdom: MacMillan Education UK (2018) 